\title{
Effect of maize straw additives on the nutritional quality and bacterial communities of ensiled forage rape for animal feed
}

\author{
Fating Yin ${ }^{1,2}$, Zhibo Cheng ${ }^{1}$, and Fenghua Zhang ${ }^{1,2^{*}}$ \\ ${ }^{1}$ Shihezi University, Agricultural College, Beiyuan Campus 832003, Shihezi, Xinjiang, China. \\ ${ }^{2}$ Shihezi University, Agricultural College, Key Laboratory of Oasis Eco-agriculture, Beiyuan Campus 832003, Shihezi, Xinjiang, \\ China. "Corresponding author (zhangfenghua6088@126.com).
}

Received: 14 April 2021; Accepted: 29 July 2021; doi:10.4067/S0718-58392021000400585

\begin{abstract}
The impact of forage rape (Brassica napus L.) with maize (Zea mays L.) straw addition on the changes of nutritional quality and bacterial community was investigated by using high-throughput sequencing analysis of the 16S rRNA. The six ensilage treatments were set based on different mass ratios of forage rape (S) and maize stalk (Y): S1 (forage rape:maize stalk 10:0), S7Y3 (7:3), S6Y4 (6:4), S5Y5 (5:5), S4Y6 (4:6), and S3Y7 (3:7). The results showed that compared with S1, the DM content of S7Y3, S6Y4, S5Y5, S4Y6 and S3Y7 increased by 10.71\%, 16.02\%, 22.56\%, 24.37\% and 30.19\% after the maize straw addition, respectively. Contents of crude protein (CP), ether extracts (EE) and water-soluble carbohydrate (WSC) contents in S7Y3 were significantly higher than that of other maize straw additive treatments $(\mathrm{P}<0.05)$, which were $11.11 \% \mathrm{DM}, 4.54 \% \mathrm{DM}$ and $12.50 \% \mathrm{DM}$, respectively. On the $60^{\text {th }}$ day of fermentation, the lowest $\mathrm{pH}$ value was found in S7Y3, which was 3.56. The V-score of each treatment were above 80. Bacterial Shannon and Chao indices were highest in S7Y3. The dominant bacterial phyla across all silage samples were Firmicutes, Proteobacteria, Cyanobacteria and Actinobacteria. The dominant genera are Lactobacillus and Weissella. Redundancy analysis (RDA) suggested that DM, CP, EE and WSC are the main factors in shaping bacterial communities. This study demonstrated that forage rape with maize straw addition can affect the nutritional quality and bacterial community of silage, and the best mixing ratio of maize straw and forage rape ensilage is $7: 3$.
\end{abstract}

Key words: Bacterial community, ensilage quality, forage rape, maize straw additives.

\section{INTRODUCTION}

Forage rape (Brassica napus L.) is one of the most important oilseed crops globally, which has been widely used for human food supply and animal forage ( $\mathrm{Lu}$ et al., 2019). Forage rape is a new type of high-protein forage (Kaur et al., 2010), content of crude protein is $270-330 \mathrm{~g} \mathrm{~kg}^{-1} \mathrm{DM}$ (Islam and Garcia, 2012). Given the strong cold tolerance and rapid growth, forage rape is widely grown in north European and China (Iqbal, 2014). In recent years, shortage of forage has become a limiting factor constraining the economic development of animal husbandry in China.

Ensilage is a well-developed technology which can preserve the nutrient component to a large extent. However, water content of forage rape is higher during the flowering period, furthermore the direct silage can easily lead to the fermentation of butyric acid and loss of nutrients, resulting in failure of fermentation and economic loss (Guo et al., 2013). Yan et al. (2019) observed that the mixing of water content of the silage and dry grain by-products is an effective way to solve those problems. Maize (Zea mays L.) straw is a rich agricultural by-product widely used as a feed resource worldwide. Maize, as one of major crops, is widely planted in north China and its straw is used as an important animal husbandry forage (Hu et al., 2018). Lamb and Evvard (1916) tried to mix forage rape with other forage grasses, including 
whole corn plant and corn grain, and pointed a mixture of rape and a legume produces the best quality of silage. Kaur et al. (2009) reported that the feeding time and sequence of forage rape and maize silage does not affect digestibility and rumen parameters in sheep. Additives are also applied to the fermentation of forage rape silage. These studies provide us with valuable experience in the research on mixed silage of forage rape and maize straw. Previous studies mainly focused on forage rape and fresh corn, and did not discuss the appropriate silage ratio of forage rape mix with dry maize straw. In addition, high-throughput sequencing technology provides an opportunity for us to understand the bacterial community under the mixed silage of forage rape and maize straw.

Bacteria, the most diverse and abundant organisms on Earth. The bacteria play a crucial role in the process of silage fermentation (Zhang et al., 2018). Affected by plant epiphytic bacteria, the bacterial community composition of different silages is different (Santoso et al., 2011). In addition, the rapid growth and reproduction of epiphytic lactic acid bacteria is beneficial to lower the $\mathrm{pH}$ of the silage and protect the silage from deterioration (Gharechahi et al., 2017). Therefore, high-quality silage raw materials are more conducive to the success of silage fermentation. Maize is widely used in the preparation of silage, which includes whole plant maize, maize straw and maize kernels. It was reported that bacterial community shift from Enterobacter to Lactococcus and Lactobacillus after fermentation in maize silage (Parvin et al., 2010). Lactobacillus stable presence contributes to the rising of lactic and acetic acid during whole-plant maize ensiling (Hu et al., 2018). The mixed silage of maize straw and other forage grass not only increases the nutrient content of silage, but also improves the fermentation flora and promotes stability of silage fermentation (Wang et al., 2019). Although predecessors conducted research on the mixed silage of whole maize and forage rape (Lamb and Evvard, 1916), knowledge on the impact of forage rape with maize straw addition on bacterial community remains poorly understood. $\mathrm{Ni}$ et al. (2018) indicated that changes in microbial communities may be responsible for differences in silage quality. Accordingly, studying the bacterial community structure of forage rape mixed with maize straw silage can help us understand the changes of beneficial or harmful bacteria, and provide data support for determining a reasonable silage ratio.

Therefore, the present study aims to investigate the effect of different maize straw and forage rape ensilage mixed ratios on silage nutritional quality and bacterial community. The objectives were to assess silage nutritional quality changes, reveal the shifts of bacterial community, and explore possible reasons leading to the changes in bacterial community and provide the rational mixing ratio of forage rape and maize straw.

\section{MATERIAL AND METHODS}

\section{Site descriptions and plant material}

This study was conducted at Zhongjiazhuang township, which is on the alluvial plain of the Manasi River Basin in Xinjiang $\left(44^{\circ} 45^{\prime} \mathrm{N}, 85^{\circ} 40^{\prime} \mathrm{E}\right)$. This region is one of the main farming-pastoral zones in northwest China. In order to make full use of the high-protein, high-fat and low-fiber of rapeseed nutritional characteristics, and solve the problem of storage, processing and utilization of rapeseed, we designed an ensilage experiment based on forage rape and supplemented by maize straw.

The forage rape (Brassica napus L.) 'Huayouza 62' seeds were provided by the Huazhong Agricultural University and silage maize straw (Zea mays L.) 'Xinsiyu 11' seeds were provided by the Shihezi University, they were harvested during the flowering period as the silage raw materials. The six ensilage treatments were set based on different mass ratios of forage rape (S) and maize stalk (Y): S1 (forage rape:maize stalk 10:0), S7Y3 (7:3), S6Y4 (6:4), S5Y5 (5:5), S4Y6 (4:6), and S3Y7 (3:7).

\section{Experimental preparation of raw materials}

The post-harvest forage rape and maize straw were manually cut into $2 \mathrm{~cm}$ sections by a forage cutter (model 9ZP-3.6, Kaiyue Machinery Company, Xuzhou, China). These two raw materials were mixed according to the ratios of S1, S7Y3, S6Y4, S5Y5, S4Y6 and S3Y7 for ensilage preparation with total weight of $1.5 \mathrm{~kg}$. After being well mixed, samples were filled into an ensilage bag for vacuum preservation and then stored at room temperature $\left(23-30{ }^{\circ} \mathrm{C}\right)$, in the dark for $60 \mathrm{~d}$. Treatments were conducted in triplicate, 5 bags per serving, a total of 15 bags. To determinate the nutrition and fermentation index, three bags were taken randomly from each treatment on 3, 7, 15, 30, $60 \mathrm{~d}$ of the fermentation, respectively. The nutrient content of raw material before ensiling is shown in Table 1. 
Table 1. Chemical properties of raw material of forage rape and maize stalk used for ensiling.

\begin{tabular}{lcrrrrr}
\hline Treatments $^{1}$ & DM & \multicolumn{1}{c}{ CP } & EE & NDF & ADF & WSC \\
\cline { 3 - 4 } & \multicolumn{1}{c}{$\%$} & & & $\%$ DM & & \\
S1 & $15.04 \pm 0.09$ & $15.16 \pm 0.12$ & $6.41 \pm 0.35$ & $42.59 \pm 0.88$ & $33.21 \pm 0.60$ & $13.91 \pm 0.42$ \\
S7Y3 & $27.75 \pm 0.20$ & $11.11 \pm 0.03$ & $4.54 \pm 0.25$ & $57.23 \pm 0.29$ & $41.12 \pm 0.28$ & $12.50 \pm 0.29$ \\
S6Y4 & $31.24 \pm 0.12$ & $10.21 \pm 0.04$ & $4.26 \pm 0.03$ & $57.95 \pm 0.33$ & $42.78 \pm 1.59$ & $12.03 \pm 0.25$ \\
S5Y5 & $37.60 \pm 0.32$ & $9.32 \pm 0.05$ & $3.30 \pm 0.05$ & $61.06 \pm 0.87$ & $42.80 \pm 0.31$ & $11.56 \pm 0.21$ \\
S4Y6 & $39.41 \pm 0.37$ & $8.43 \pm 0.06$ & $3.23 \pm 0.16$ & $63.84 \pm 0.58$ & $42.84 \pm 0.57$ & $11.10 \pm 0.08$ \\
S3Y7 & $45.23 \pm 0.47$ & $7.54 \pm 0.07$ & $3.03 \pm 0.02$ & $66.33 \pm 0.42$ & $43.12 \pm 0.47$ & $10.61 \pm 0.13$ \\
\hline
\end{tabular}

${ }^{1}$ Forage rape (S) and maize stalk $(\mathrm{Y})$ ratio (S:Y). S1: 10:0; S7Y3: 7:3; S6Y4: 6:4; S5Y5: 5:5; S4Y6: 4:6; S3Y7: 3:7.

DM: Dry matter; CP: crude protein; EE: ether extracts; NDF: neutral detergent fiber; ADF: acid detergent fiber; WSC: water-soluble carbohydrate.

\begin{abstract}
Analytical methods
Determination of fermentation nutrition index. Approximately $100 \mathrm{~g}$ samples were analyzed for DM content by oven drying at $65{ }^{\circ} \mathrm{C}$ for $48 \mathrm{~h}$ and then ground to pass a $1 \mathrm{~mm}$ screen by a laboratory knife mill (FW100, Taisite Instrument, Tianjin, China). Crude protein (CP) was measured using the Kjeldahl N analyzer (KDY-9830, Ketuo Instrument, Beijing, China) according to the methods of Association of Official Analytical Chemists (AOAC, 2012). The ether extracts (EE) content was determined by Soxhlet extraction. The neutral detergent fiber (NDF) and acid detergent fiber (ADF) contents were analyzed without amylase, using the sulphite method. The water-soluble carbohydrate (WSC) content was determined according to the thracenone-sulphuric acid method (AOAC, 2012).
\end{abstract}

Organic acid and chemical composition. A sample of fresh silage $(20 \mathrm{~g})$ was added to $180 \mathrm{~mL}$ distilled water and shaken for $5 \mathrm{~min}$, allowed to stand for $50 \mathrm{~min}$, after 3 cycles stand for $10 \mathrm{~min}, \mathrm{pH}$ value of filtrate form silage was measured by electrode $\mathrm{pH}$ meter (PHSJ-5; LEICI, Shanghai, China). Ammonia $\mathrm{N}\left(\mathrm{NH}_{3}-\mathrm{N}\right)$ was measured by phenol-hypochlorous acid colorimetric method. Volatile fatty acid (VFA) was measured by high pressure liquid chromatography (HPLC) system (LCMS-2020; Shimadzu, Tokyo, Japan). The samples were investigated using an isocratic elution $0.2 \% \mathrm{H}_{3} \mathrm{PO}_{4}$ at $1 \mathrm{~mL} \mathrm{~min}^{-1}$ and column temperature of $50^{\circ} \mathrm{C}$. The wavelength was $210 \mathrm{~nm}$ (Yu et al., 2016). The V-score is an important index for comprehensively evaluate ensilage fermentation quality, which was calculated to evaluate the fermentative quality based on the values of organic acids and $\mathrm{NH}_{3}-\mathrm{N}$ content.

\title{
Bacterial diversity analysis
}

DNA extraction and PCR amplification. After $60 \mathrm{~d}$ of ensiling, the triplicate samples from each treatment were opened, well mixed for analysis of bacterial community. Total DNA was extracted from silage samples using a Power Soil DNA Isolation kit (MP Biomedicals, Santa Ana, California, USA) following kit instructions. The V3-V4 hypervariable regions of bacterial 16S rRNA gene were amplified using the primer pair 338F/806R. The V3-V4 regions of each silage sample were amplified using PCR $\left(27\right.$ cycles of denaturation at $95{ }^{\circ} \mathrm{C}$ for $30 \mathrm{~s}$, annealing at $55^{\circ} \mathrm{C}$ for $30 \mathrm{~s}$, extension at $72{ }^{\circ} \mathrm{C}$ for $45 \mathrm{~s}$, a final extension at $72{ }^{\circ} \mathrm{C}$ for $10 \mathrm{~min}$, and holding at $10^{\circ} \mathrm{C}$ ). PCR reactions were performed in triplicate, $20 \mu \mathrm{L}$ mixture containing $4 \mu \mathrm{L} 5 \times$ FastPfu buffer, $2 \mu \mathrm{L} 2.5 \mathrm{mM}$ dNTPs, $0.8 \mu \mathrm{L}$ each primer $(5 \mu \mathrm{M}), 0.4 \mu \mathrm{L}$ FastPfu Polymerase and $10 \mathrm{ng}$ template DNA. The resulted PCR products were extracted from a $2 \%$ agarose gel and further purified using the AxyPrep DNA gel extraction kit (Axygen Biosciences, Union City, California, USA) and quantified using a fluorometer (QuantiFluor-ST, Promega, Madison, Wisconsin, USA) according to the manufacturer's protocol.

Illumina MiSeq sequencing. Purified amplicons were pooled in equimolar and paired-end sequenced $(2 \times 300)$ on an Illumina MiSeq platform (Illumina, San Diego, California, USA) according to the standard protocols by Majorbio BioPharm Technology (Shanghai, China).

Processing of sequencing data. Raw FASTQ files (Illumina) were demultiplexed, quality filtered by Trimmomatic and merged by FLASH software (Center for Computational Biology, Johns Hopkins University, Washington D.C, USA. https://ccb.jhu.edu/software/FLASH/index.shtml) with the following criteria: (i) reads were truncated at any site receiving an average quality score $<20$ over a 50 bp sliding window, (ii) primers were exactly matched allowing 2 nucleotide 
mismatching and reads containing ambiguous bases were removed, (iii) sequences whose overlap longer than 10 bp were merged according to their overlap sequence. Operational taxonomic units (OTUs) were clustered with 97\% similarity cutoff using UPARSE and chimeric sequences were identified and removed using UCHIME. The taxonomy of each 16S rRNA gene sequence was analyzed by RDP classifier algorithm against the Silva (SSU123) 16S rRNA database (SILVA ribosomal RNA database project; Max Planck Institute for Marine Microbiology and Jacobs University, Bremen, Germany) using confidence threshold of $70 \%$.

\section{Statistical analysis}

The data from ensiling was statistically analyzed using SPSS 19.0 software (SPSS Inc., Chicago, Illinois, USA). One-way ANOVA was used for comparisons. Using the Bary Curts metric matrix, a hierarchical clustering tree was constructed to compare the composition of bacterial communities in all samples. CANOCO 5 was used to perform the redundancy analysis (RDA) analysis. The figures of the nutrition-fermentation quality changes and relative abundance of bacterial community were performed using Origin version 9.0 (Microcal Software, Northampton, Massachusetts, USA).

\section{RESULTS}

\section{Changes in nutrition quality during silage fermentation}

In this study, DM content increased significantly after maize straw addition, the highest value was found in S3Y7, while it was lowest in S1. But CP, EE and WSC contents decreased with the increasing maize straws proportion (Table 1), their contents in S7Y3 was higher than maize straw additive treatments $(\mathrm{P}<0.05)$.

The changes of nutrient quality under different treatments during fermentation are shown in Figure 1. The content of DM, EE and CP under different treatments was gradually decreased as the fermentation process progresses. On the $60^{\text {th }}$ day, DM content was the highest in S3Y7, while it was lowest in S1. The highest EE and CP contents were 3.07\% and $12.98 \%$ in S1, respectively. Contents of EE and CP in S7Y3 were significantly higher than that of other maize straw additive treatments $(\mathrm{P}<0.05)$. On the $60^{\text {th }}$ day, the significant highest WSC content was found in S7Y3 treatment $(\mathrm{P}<0.05)$. In this study, NDF and ADF content under different treatments decreased significantly with the increasing fermentation days $(\mathrm{P}<0.05)$. On the $60^{\text {th }}$ day, the content of ADF and NDF in S7Y3 was significantly lower than those in other treatments $(\mathrm{P}<0.05)$.

Figure 1. The changes of nutrition-fermentation quality during silage fermentation.
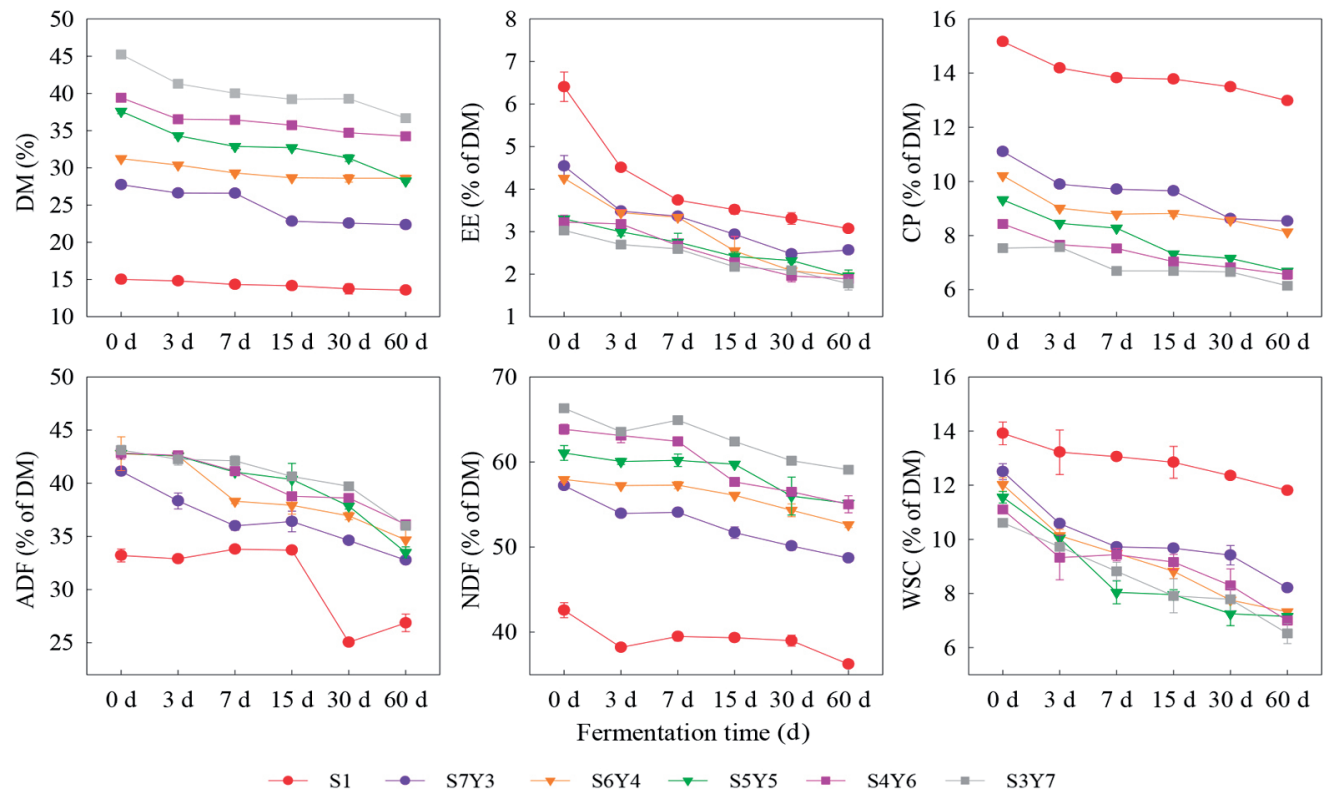

Forage rape (S) and maize stalk (Y) ratio. S1: 10:0; S7Y3: 7:3; S6Y4: 6:4; S5Y5: 5:5; S4Y6: 4:6; S3Y7: $3: 7$.

DM: Dry matter; EE: ether extracts; CP: crude protein; ADF: acid detergent fiber; NDF: neutral detergent fiber; WSC: water-soluble carbohydrate. 


\section{Fermentative quality of silages}

As shown in Table 2, the maize straw addition had significant effect on fermentation characteristics of forage rape silage $(\mathrm{P}<0.05)$. On the $60^{\text {th }}$ day of fermentation, $\mathrm{pH}$ values of all treatments were below 4.0, with the lowest in S7Y3 and highest in S5Y5. The changes of lactic acid (LA), acetic acid (AA) and propionic acid (PA) content had same trend under different treatments, namely, content of LA, AA and PA increased gradually with the increasing maize straw addition. The higher LA and AA contents were observed in all treatments, and a small amount of butyric acid (BA) (less than $0.05 \%$ $\mathrm{DM})$. We found no differences in $\mathrm{NH}_{3}-\mathrm{N}$ content between $\mathrm{S} 1, \mathrm{~S} 7 \mathrm{Y} 3$ and $\mathrm{S} 3 \mathrm{Y} 7(\mathrm{P}>0.05)$. The higher $\mathrm{NH}_{3}-\mathrm{N}$ content was observed in S6Y4 and S4Y6 ( $\mathrm{P}<0.05)$. The $\mathrm{V}$-score scoring system calculated the score respectively and total score to obtain final evaluation score based on the content of VFA and $\mathrm{NH}_{3}-\mathrm{N}$ in silage. The scores of each treatment were above 80 (Table 2). The V-score decreased after the maize straw addition, S1 treatment exhibited significantly higher V-score compare to other treatments. With the increase of maize straw addition ratio, LA content increased gradually.

\section{Silage fermentation bacterial community diversity and composition}

As shown in Table 3, there were a total of 902 OTUs from six treatments. The number of high-quality sequences per sample varied from 58841 to 66202 with an average of 62521 sequences. Microbial diversity index can reflect the diversity and richness of biological populations. Shannon and Simpson indexes can reflect the community diversity, and Chao index can reflect the community richness. The species richness based on Chao1 index showed that S7Y3 and S1 exhibited the highest richness (Table 3). S7Y3 and S1 had the highest Shannon index in this study. In contrast, these two treatments displayed the lowest Simpson indices ( 0.17 and 0.17 , respectively). The coverage of all samples is above 0.99 , suggesting that the sequencing reads were sufficient for this analysis.

The dominant phyla across all samples were Firmicutes, Proteobacteria, Cyanobacteria and Actinobacteria (Figure 2a). The highest relative abundance of Firmicutes $(88.47 \%$ ) was observed in S3Y7. Abundance of Firmicutes increased as the proportion of maize straws increases. However, the relative abundance of Proteobacteria decreased as the proportion of maize straws increases. Abundance of Firmicutes and Proteobacteria performed the opposite trend. There was nonsignificant change in the relative abundance of Cyanobacteria and Actinobacteria.

Table 2. Effect of different maize stalk additions on fermentation characteristics of forage rape silage.

\begin{tabular}{lcrrrrrr}
\hline & \multicolumn{7}{c}{ Treatments $^{1}$} \\
\cline { 2 - 8 } Items & \multicolumn{1}{c}{$\mathrm{S} 1$} & $\mathrm{~S} 7 \mathrm{Y} 3$ & $\mathrm{~S} 6 \mathrm{Y} 4$ & $\mathrm{~S} 5 \mathrm{Y} 5$ & \multicolumn{1}{c}{ S4Y6 } & S3Y7 & SEM \\
\hline $\mathrm{pH}$ & $3.72 \mathrm{ab}$ & $3.56 \mathrm{c}$ & $3.65 \mathrm{~b}$ & $3.76 \mathrm{a}$ & $3.70 \mathrm{ab}$ & $3.69 \mathrm{ab}$ & 0.02 \\
$\mathrm{NH}_{3}-\mathrm{N}, \% \mathrm{TN}$ & $8.69 \mathrm{~b}$ & $8.63 \mathrm{~b}$ & $9.77 \mathrm{a}$ & $7.72 \mathrm{c}$ & $9.84 \mathrm{a}$ & $8.55 \mathrm{~b}$ & 0.16 \\
$\mathrm{LA}, \% \mathrm{DM}$ & $0.57 \mathrm{e}$ & $0.94 \mathrm{~d}$ & $1.19 \mathrm{c}$ & $1.19 \mathrm{c}$ & $1.42 \mathrm{~b}$ & $1.53 \mathrm{a}$ & 0.02 \\
$\mathrm{AA}, \% \mathrm{DM}$ & $0.44 \mathrm{e}$ & $0.73 \mathrm{~d}$ & $0.90 \mathrm{c}$ & $0.88 \mathrm{c}$ & $1.09 \mathrm{~b}$ & $1.16 \mathrm{a}$ & 0.02 \\
$\mathrm{PA}, \% \mathrm{DM}$ & $0.08 \mathrm{~d}$ & $0.11 \mathrm{c}$ & $0.14 \mathrm{~b}$ & $0.15 \mathrm{~b}$ & $0.17 \mathrm{a}$ & $0.18 \mathrm{a}$ & 0.01 \\
$\mathrm{BA}, \% \mathrm{DM}$ & $0.00 \mathrm{e}$ & $0.01 \mathrm{~d}$ & $0.01 \mathrm{c}$ & $0.01 \mathrm{~b}$ & $0.01 \mathrm{~b}$ & $0.01 \mathrm{a}$ & 0.00 \\
V-score & $89.89 \mathrm{a}$ & $87.15 \mathrm{~b}$ & $83.16 \mathrm{c}$ & $87.42 \mathrm{~b}$ & $81.34 \mathrm{e}$ & $83.28 \mathrm{c}$ & 0.39 \\
\hline
\end{tabular}

Means with different letters within each row are significantly different at $\mathrm{P}<0.05$.

${ }^{1}$ Forage rape (S) and maize stalk (Y) ratio (S:Y). S1: 10:0; S7Y3: 7:3; S6Y4: 6:4; S5Y5: 5:5; S4Y6: 4:6; S3Y7: 3:7.

SEM: Standard error of the mean; LA: lactic acid; AA: acetic acid; PA: propionic acid; BA: butyric acid; TN: Total nitrogen; DM: dry matter.

Table 3. General information of sequence and bacterial diversity.

\begin{tabular}{lcccccc}
\hline $\begin{array}{l}\text { Sample } \\
\text { ID }^{1}\end{array}$ & $\begin{array}{c}\text { Number of } \\
\text { read }\end{array}$ & $\begin{array}{c}\text { Number of } \\
\text { OTUs }\end{array}$ & $\begin{array}{c}\text { Shannon } \\
\text { index }\end{array}$ & $\begin{array}{c}\text { Simpson } \\
\text { index }\end{array}$ & $\begin{array}{c}\text { Chao1 } \\
\text { index }\end{array}$ & $\begin{array}{c}\text { Coverage } \\
\text { index }\end{array}$ \\
\hline S1 & 65124 & 156 & 2.28 & 0.17 & 181.59 & 0.99 \\
S7Y3 & 66202 & 153 & 2.21 & 0.17 & 188.06 & 0.99 \\
S6Y4 & 63851 & 155 & 1.99 & 0.24 & 168.80 & 0.99 \\
S5Y5 & 58841 & 130 & 1.91 & 0.30 & 170.63 & 0.99 \\
S4Y6 & 62819 & 156 & 2.15 & 0.21 & 172.87 & 0.99 \\
S3Y7 & 65230 & 152 & 1.82 & 0.28 & 163.55 & 0.99 \\
\hline
\end{tabular}

${ }^{1}$ Forage rape (S) and maize stalk $(\mathrm{Y})$ ratio $(\mathrm{S}: \mathrm{Y})$. S1: 10:0; S7Y3: 7:3; S6Y4: 6:4; S5Y5: 5:5; S4Y6: 4:6; S3Y7: $3: 7$. 
Figure 2. Relative abundance of soil bacterial community at the phylum (a), family (b), and genus (c) levels across the different treatments.
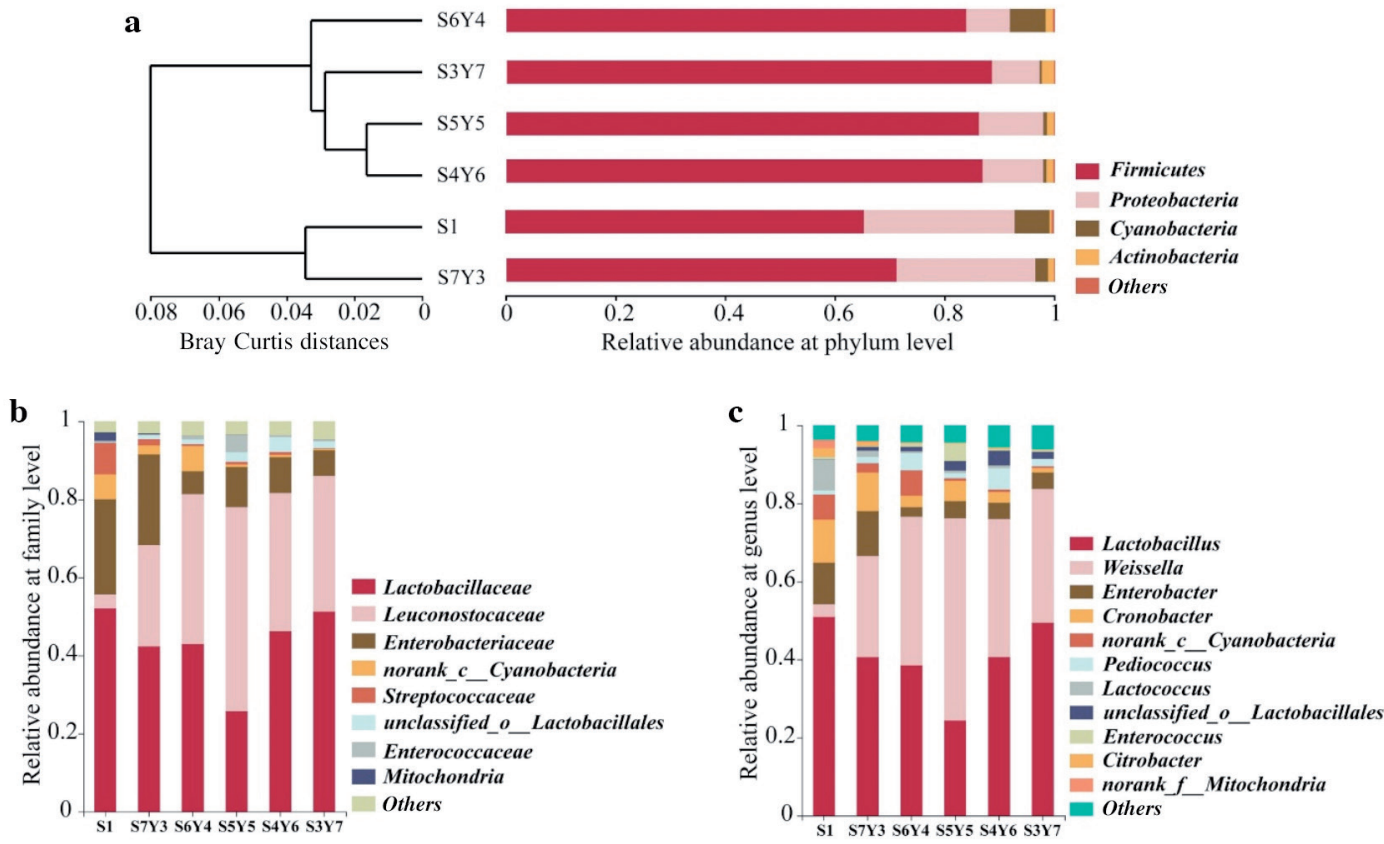

Forage rape (S) and maize stalk (Y) ratio (S:Y). S1: 10:0; S7Y3: 7:3; S6Y4: 6:4; S5Y5: 5:5; S4Y6: 4:6; S3Y7: 3:7.

At the family levels (Figure 2b), Lactobacillaceae and Leuconostocaceae were dominant families. The total relative abundances of Lactobacillaceae and Leuconostocaceae were more than $55.67 \%$ under different treatments. The relative abundance of Lactobacillaceae decreased after adding maize straws, the highest relative abundance was observed in S1 $(52.12 \%)$. However, the relative abundance of Leuconostocaceae increased after adding maize straws, the highest relative abundance was observed in S5Y5 (52.34\%). In summary, the total relative abundances of Lactobacillaceae and Leuconostocaceae increased as the proportion of maize straws increases.

Further comparison of the bacterial communities was conducted at the genus levels (Figure 2c). The comparisons of the relative abundances of the top 11 classified bacterial genus $(>0.02 \%)$ showed differences among the treatments (Figure 2c). The dominant genus Lactobacillus and Weissella were enriched in all samples. Members of the genus Enterobacter, Cronobacter, Pediococcus, Lactococcus, Enterococcus and Citrobacter were also present in all samples. We observed that the total relative abundance of Enterobacter and Cronobacter decreased gradually after maize straw addition. The relative abundance of Enterobacter was $10.63 \%$ in S1. Enterobacter abundance was $2.47 \%$ in S6Y4.

The genus Lactobacillus and Weissella, which belongs to phylum Firmicutes, were enriched in all treatments (Figure 2). The abundance of Lactobacillus was 50.92\% in S1 and 24.35\% in S5Y5. While the abundance of Weissella was only $3.25 \%$ in S1. After maize straws addition, the relative abundance of Weissella increased significantly, and the highest abundance was $51.82 \%$ in S5Y5.

\section{Correlations between silage nutritional quality and bacterial community}

The nutritional quality of silage has a significant impact on the bacterial community. Results of RDA analysis indicated a significant correlation between silage nutrition quality and abundant phyla $(\mathrm{P}<0.05)$. The first two axes of RDA axis explained $97.71 \%$ of total variation (Figure 3, Table 4). The first component (RDA1) separated samples from different treatments and explained $82.05 \%$ of variation. A much better discrimination exhibited at phyla level, and S3Y7, S4Y6, S5Y5 treatment cluster together, where S6Y4 and S7Y3 distinctly separated from other treatments. This result indicated that maize straw addition has a significant impact on bacterial community at phyla level. The RDA plots of bacterial community structure clearly also showed that CP, WSC, EE, DM, NDF and ADF are the longer arrows, with their direction closely correlated to the RDA1 axis, respectively (Figure 4). We have also observed that CP, WSC and EE positively 
correlated with the relative abundance of Proteobacteria, and negatively correlated with Firmicutes and Actinobacteria (Figure 5a). But DM, NDF and ADF positively correlated with Firmicutes and Actinobacteria, and negatively correlated with Proteobacteria.

Figure 3. Redundancy analysis (RDA) to show correlation between silage nutritional quality and dominant bacterial phyla.

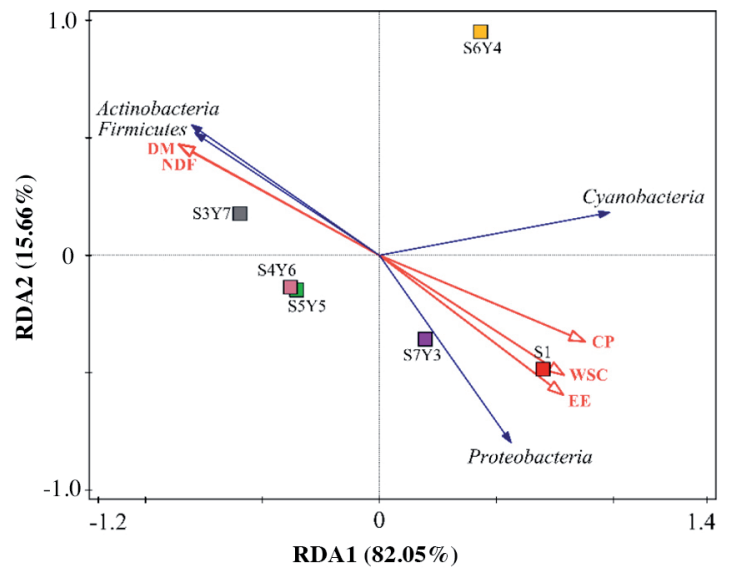

Forage rape (S) and maize stalk (Y) ratio (S:Y). S1: 10:0; S7Y3: 7:3; S6Y4: 6:4; S5Y5: 5:5; S4Y6: 4:6; S3Y7: 3:7.

DM: Dry matter; CP: crude protein; WSC: water-soluble carbohydrate; EE: ether extracts; NDF: neutral detergent fiber.

Table 4. Correlation between nutritional quality parameters and redundancy analysis (RDA) axes at phyla level.

\begin{tabular}{lcccc}
$\begin{array}{l}\text { Nutritional quality } \\
\text { parameters }\end{array}$ & RDA1 & RDA2 & $\mathrm{R}^{2}$ & P values \\
\hline DM & 0.956 & -0.295 & 0.995 & 0.001 \\
CP & -0.936 & 0.363 & 0.865 & 0.010 \\
EE & -0.998 & 0.071 & 0.967 & 0.003 \\
NDF & 0.957 & -0.289 & 0.920 & 0.011 \\
WSC & -0.964 & 0.267 & 0.853 & 0.003 \\
\hline
\end{tabular}

DM: Dry matter; CP: crude protein; EE: ether extracts; NDF: neutral detergent fiber; WSC: watersoluble carbohydrate.

Figure 4. Redundancy analysis (RDA) results of abundant genus and silage nutritional quality for samples from different treatments.

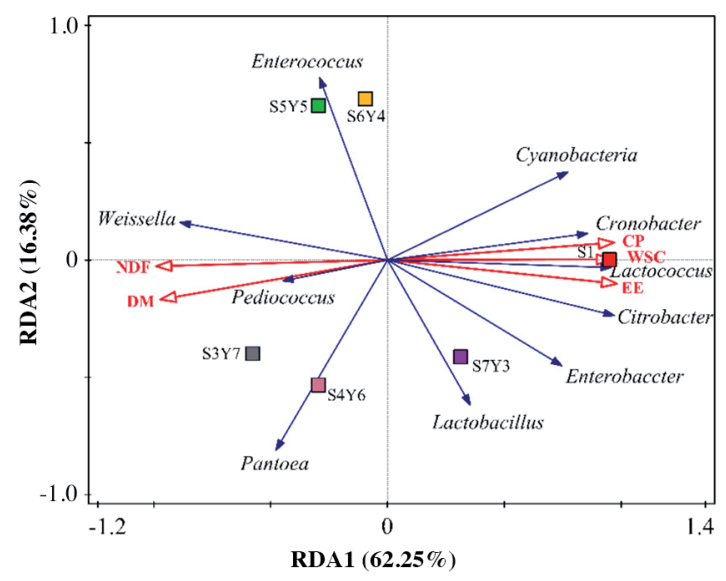

Forage rape (S) and maize stalk (Y) ratio (S:Y). S1: 10:0; S7Y3: 7:3; S6Y4: 6:4; S5Y5: 5:5; S4Y6: 4:6; S3Y7: 3:7.

DM: Dry matter; CP: crude protein; WSC: water-soluble carbohydrate; EE: ether extracts; NDF: neutral detergent fiber. 
Figure 5. Correlation between silage nutritional quality indices and bacterial community at phyla (a) and genus (b) levels.

a

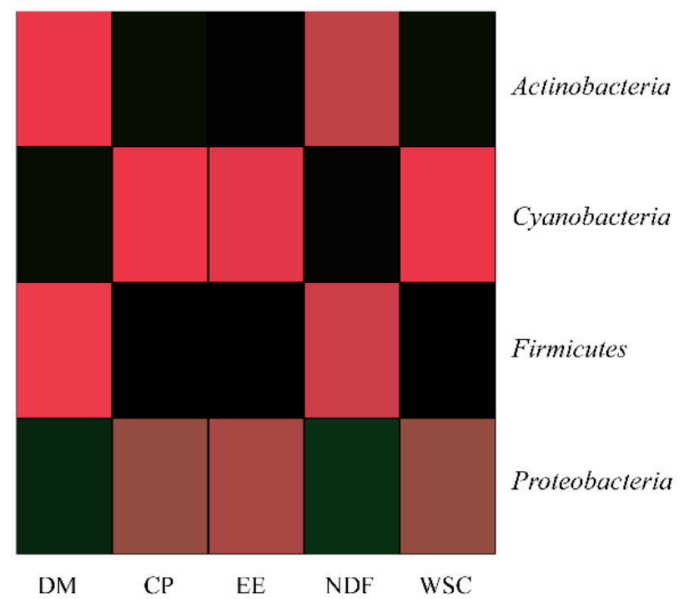

b

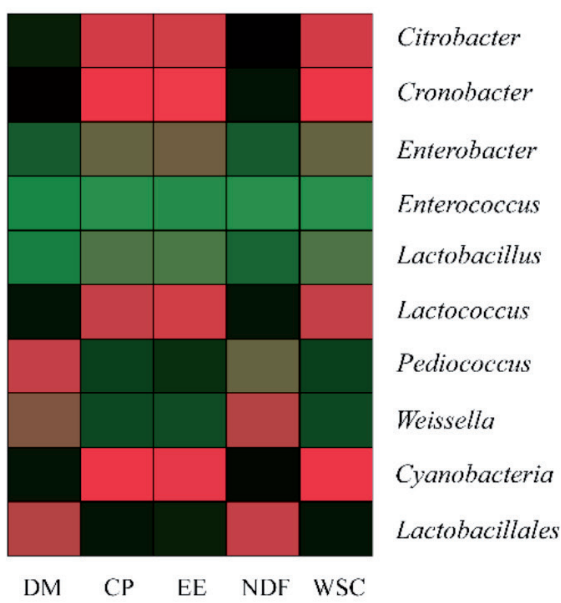

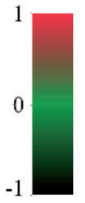

DM: Dry matter; CP: crude protein; EE: ether extracts; NDF: neutral detergent fiber; WSC: water-soluble carbohydrate.

RDA analysis of the silage nutritional quality and abundant genus indicated that RDA1 and RDA2 explain 62.25\% and $16.38 \%$ bacterial community variation, respectively (Figure 4, Table 5). S1 separated S6Y4, S3Y7, S4Y6 and S5Y5 on the RDA1 axis, indicating that maize straw addition not only has significant effect on CP, WSC, EE, DM, NDF and ADF, but also impact bacterial community. Pearson correlation coefficient showed that CP, WSC and EE contents positively correlated with Cronobacter, Lactococcus and Citrobacter, contents positively correlated with Enterobacter (Figure 5b, $\mathrm{P}<0.05)$. While the content of DM, NDF and ADF negatively Cronobacter, Lactococcus and Citrobacter, NDF and ADF content positively correlated with Weissella. While the content of DM negatively correlated with Enterobacter. The CP positively correlated with Cyanobacteria and EE positively correlated with Weissella, $\mathrm{NH}_{3}-\mathrm{N}$ contents positively correlated with Pediococcus.

\section{DISCUSSION}

\section{Effect of nutrition quality}

Mixed silage is an effective way to solve the problem of higher water content and insufficient nutrient content in single forage silage. To a large extent, the ensilage fermentation process is influenced by the DM content of biomass, and lactic acid bacteria (LAB) responsible for fermentation require moisture for their growth and reproduction. Zhao et al. (2019) reported increased DM content and reduced moisture by mixing lucerne and sweet corn stalk silage. In this study, DM content increased after maize straw addition to ensilage, this shows that adding maize straw helps to increase DM content of forage rape and promotes fermentation. However, the CP, EE and WSC content of silage decreased with the increasing maize straws proportion before silage because maize straws contained lower CP, EE and WSC contents (Zhao et al., 2019). In addition, due to bacterial growth and reproduction require nutrients under anaerobic conditions (Kung et al., 2018), content of CP, EE and WSC under different treatments was gradually decreased as the fermentation process

Table 5. Correlation between nutritional quality parameters and redundancy analysis (RDA) axes at genus level.

\begin{tabular}{lcccc}
$\begin{array}{l}\text { Nutritional quality } \\
\text { parameters }\end{array}$ & RDA1 & RDA2 & $\mathrm{R}^{2}$ & P values \\
\hline DM & -0.688 & -0.726 & 0.952 & 0.010 \\
CP & 0.886 & 0.463 & 0.893 & 0.033 \\
EE & 0.823 & 0.568 & 0.996 & 0.008 \\
NDF & -0.838 & -0.545 & 0.943 & 0.018 \\
WSC & 0.872 & 0.490 & 0.921 & 0.014 \\
\hline
\end{tabular}

DM: Dry matter; CP: crude protein; EE: ether extracts; NDF: neutral detergent fiber; WSC: watersoluble carbohydrate. 
progresses. Generally, the higher the content of CP, EE and WSC in silage, the greater nutritional value. Therefore, the high ratio of maize straws is not conducive to maintaining the nutrient content of silage. NDF has been characterized as the most important factor affecting the total diet organic matter digestibility (Britos et al., 2018). The lower ADF indicated the higher digestibility (Nazli et al., 2019). In our study, NDF and ADF content under different treatments decreased significantly with the increasing fermentation days $(\mathrm{P}<0.05)$, which could be explained by the produced organic acids hydrolyzing the more digestible cell wall fraction during ensiling (Larsen et al., 2017). On the $60^{\text {th }}$ day, the significantly highest CP, EE and WSC content were found in S7Y3 treatment $(\mathrm{P}<0.05)$, the content of ADF and NDF in S7Y3 was significantly lower than those in other maize straw additive treatments $(\mathrm{P}<0.05)$. This due to that maize straw contained higher NDF and ADF contents, and the lowest maize straw content in S7Y3 treatment. These results indicated that S7Y3 may have a higher nutritional value and digestibility. This provides a basis for determining the reasonable mixed silage ratio of forage rape and maize straw.

\section{Fermentative quality of the silages}

Lower $\mathrm{pH}$ is conducive to successful fermentation. The drop of $\mathrm{pH}$ in this study could be explained by increasing lactic acid (LA) and acetic acid (AA) content during the fermentation. Contents of LA, AA and PA increased with the increasing maize straw addition. The higher LA and AA contents have been observed in all treatments and the lowest $\mathrm{pH}$ values in S7Y3. This could be explained by more organic acids produced when silage was mixed with high WSC and moisture content forages (Wang et al., 2018). Xue et al. (2017) also indicated that desert wormwood ensiled with highmoisture maize (corn) straw had lower $\mathrm{pH}$ and AA concentration and higher LA concentration as the proportion of desert wormwood decreased. However, Yan et al. (2019) reported that AA content of the Italian ryegrass silages was low or less than $0.01 \% \mathrm{DM}$. This inconsistent result in our study is probably attributed to the bacterial communities of the silages being from different conditions, materials, or microbe on the raw materials (Guan et al., 2018). Conversion of LA to BA is one of the most wasteful anaerobic fermentations in silage. Muck (2010) indicated that BA is undesirable during ensilage fermentation because it reduces the intake of livestock if over 0.05\% DM. A small amount of BA was detected in this study indicating that maize straw addition cannot introduce undesirable fermentation.

The amount of $\mathrm{NH}_{3}-\mathrm{N}$ present in silage is a reliable indicator of the extent of proteolytic clostridial activity, this may also be the performance of CP reduction (Zheng et al., 2017). This has also been confirmed in our study, as the CP content decreases, $\mathrm{NH}_{3}-\mathrm{N}$ content gradually increases. Simultaneously, increasing $\mathrm{NH}_{3}-\mathrm{N}$ content lowers $\mathrm{V}$-score. The V-score method was adopted to evaluate the silage quality by calculating $\mathrm{NH}_{3}-\mathrm{N}$ and VFA contents ( $\mathrm{Li}$ et al., 2017). This method is widely used in the evaluation of fermentation quality of other silage. Lower scores indicate the higher the rate of hydrolysis of the crude protein, the higher VFA content of heterofermentative (Zhao et al., 2019). The higher V-score, the better silage quality (Cao et al., 2010). And we found that $\mathrm{V}$-score decreased after the maize straw addition, this indicates that an excessive increase in the proportion of maize straw will not improve the silage quality.

\section{Diversity and composition of silage fermentation bacterial community}

To a large extent, the silage quality is determined by microbes during silage fermentation. Shannon and Chao 1 indices decreased gradually after maize straw addition, this is due to addition of corn stalks reduced the nutrients required for bacterial reproduction and $\mathrm{LAB}$ dominates and inhibits reproduction of other bacteria.

Abundance of Firmicutes increased as the proportion of maize straws increases, but the relative abundance of Proteobacteria decreased. Hu et al. (2018) noted that Firmicutes was the dominant species for whole-plant maize fermentation. The addition of maize straw may be the main cause of the Firmicute and Proteobacteria differences. The genus Lactobacillus and Weissella, which belong to phyla Firmicutes, were enriched in all treatments (Figure 2). These two genera were also documented in similar study (Guan et al., 2018), suggesting that they were beneficial bacteria to ensilage fermentation. Weissella is strictly heterofermentative, producing a mixture of LA and AA by metabolizing WSC and certain LAB have the ability to transform LA to AA (Graf et al., 2016). In this study, each treatment contained a higher content of AA, and the relative abundance of Weissella, and both of them first increased and then decreased along with the increasing of maize straw proportion. This further confirmed that the increase in AA was due to the increase in the relative abundance of LAB and Weissella in our study. Members of the genus Enterobacter, Cronobacter, Cyanobacteria, Lactococcus, Enterococcus and Citrobacter were also present in all samples, but at very low abundance. In fact, the 
above bacteria were found in various maize and grass ensilages (Yang et al., 2017), indicating that these genera were not unique in our study. Among them, Enterobacter and Cyanobacteria are often considered as harmful indicators affecting the ensilage fermentation (Duniere et al., 2017). Fortunately, we observed that the relative abundance of Enterobacter and Cyanobacteria decreased gradually after maize straw addition.

\section{Correlations between silage nutritional quality and bacterial community}

The addition of maize straw has an important impact on the bacterial community composition at the end of fermentation. The reason for this difference may be related to the epiphytic bacteria of maize straw. Relevant studies have pointed out that the epiphytic lactic acid bacteria of corn stover grows rapidly after the start of anaerobic fermentation, and occupy a dominant position (Gharechahi et al., 2017). When silage is exposed to the air, it will promote the growth and reproduction of aerobic bacteria and cause the silage decay (Da Silva et al., 2015). Different compaction densities of silage also have an important impact on the composition of the bacterial community. Tian et al. (2020) pointed out that increasing the compaction density will inhibit growth and reproduction of harmful bacteria. Compared with single silage, mixed silage is more susceptible to the influence of epiphytic bacteria and nutritional quality of silage raw materials. The RDA analysis of the silage nutritional quality and abundant genus indicated that CP, WSC, EE, DM, NDF and ADF were significantly associated with bacterial community at phyla and genus levels (Figure 5). This relationship may be mutual. For example, WSC can be used easily by bacteria and plays a major role in shaping bacterial community structure (Duniere et al., 2017). During the fermentation process, some microorganisms consume WSC and CP to decompose the NDF and ADF by producing cellulase (Yan et al., 2019). It is generally supposed that Lactobacillus quickly come to dominate by consuming nutrients in silage (McGarvey et al., 2013). We investigated the bacterial component at the fermentation end point, Lactobacillus also dominate. This is consistent with many reports on silage bacterial community (Yang et al., 2016). Maize straw addition has significant effect on the content of CP, WSC, EE and DM, this may lead to differences in the fermentation substrate of the bacteria during the fermentation process and bacterial communities at the fermentation end point. Regrettably, we did not pay attention to changes in bacterial communities throughout the silage process. This makes it impossible for us to understand in detail the succession changes of epiphytic bacteria during the silage process. Epiphytic bacteria also have a great influence on the fermentation of silage. Gharechahi et al. (2017) reported that the Weissella is the dominant genus of maize straw epiphytic bacteria. We observed that CP, WSC and EE negatively correlated with Weissella. But NDF and ADF positively correlated with Weissella. The relative abundance of Weissella decreased with the increasing maize straws proportion. These results showed that maize straws affect the bacterial community of silage through epiphytic bacteria and nutrient content. Previous studies have observed that $\mathrm{pH}$ is the main predictor of bacterial community during silage fermentation (Guan et al., 2018). But there was nonsignificant relationship between $\mathrm{pH}$ and bacterial communities in our study, since the former did not change markedly (ranged from 3.56 to 3.76 ) in response to maize straw addition.

\section{CONCLUSIONS}

Silage nutritional quality and bacterial community were affected by maize straw addition. Appropriate ratio of maize straw addition not only ensured the proper moisture, but also ensured contents of crude protein, ether extracts and watersoluble carbohydrate content, this will be helpful to obtain high quality silage. The dominant genera are Lactobacillus and Weissella in silage. The best mixing ratio of forage rape and maize straw ensilage is 7:3.

\section{ACKNOWLEDGEMENTS}

This research was financially supported by the Special Fund for Agro-scientific Research in the Public Interest of China (201503120) and National Key Technology R \& D Program (Grant Nr 2016YFC0501406). We gratefully acknowledge helpful comments by the anonymous referees who stimulated significant improvements in the analysis and English editing. 


\section{REFERENCES}

AOAC. 2012. Official methods of analysis of AOAC International. 19 $9^{\text {th }}$ ed. Association of Official Analytical Collaboration (AOAC), Gaithersburg, Maryland, USA.

Britos, A., Repetto, J.L., and Cajarville, C. 2018. Does it make a difference supplementing pasture silage with starchy concentrates or soyhulls on intake, digestion and rumen environment? Livestock Science 218:85-91. https://doi.org/10.1016/j.livsci.2018.09.021.

Cao, Y., Takahashi, T., Horiguchi, K.I., and Yoshida, N. 2010. Effect of adding lactic acid bacteria and molasses on fermentation quality and in vitro ruminal digestion of total mixed ration silage prepared with whole crop rice. Grassland Science 56:1925. https://doi.org/10.1111/j.1744-697x.2009.00168.x.

Da Silva, T.C., Smith, M.L., Barnard, A.M., and Kung, J.L. 2015. The effect of a chemical additive on the fermentation and aerobic stability of high-moisture corn. Journal of Dairy Science 98:8904-8912. https://doi.org/10.3168/jds.2015-9640.

Duniere, L., Xu, S., Long, J., Elekwachi, C., Wang, Y., Turkington, K., et al. 2017. Bacterial and fungal core microbiomes associated with small grain silages during ensiling and aerobic spoilage. BMC Microbiology 17:50. https://doi.org/10.1186/s12866-017-0947-0.

Gharechahi, J., Kharazian, Z.A., Sarikhn, S., Jouzani, G.S., Aghdasi, M., and Hosseini, S.G. 2017. The dynamics of the bacterial communities developed in maize silage. Microbial Biotechnology 10(6):16631676. https://doi.org/10.1111/1751-7915.12751

Graf, K., Ulrich, A., Idler, C., and Klocke, M. 2016. Bacterial community dynamics during ensiling of perennial ryegrass at two compaction levels monitored by terminal restriction fragment length polymorphism. Journal of Applied Microbiology 120:1479-1491. https://doi.org/10.1111/jam.13114.

Guan, H., Yan, Y., Li, X., Li, X., Shuai, Y., Feng, R., et al. 2018. Microbial communities and natural fermentation of corn silages prepared with farm bunker-silo in Southwest China. Bioresource Technology 265:282-290. https://doi.org/10.1016/j.biortech.2018.06.018.

Guo, X.S., Undersander, D.J., and Combs, D.K. 2013. Effect of Lactobacillus inoculants and forage dry matter on the fermentation and aerobic stability of ensiled mixed-crop tall fescue and meadow fescue. Journal of Dairy Science 96(3):1735-1744. https://doi.org/10.3168/jds.2045-5786.

Hu, Z., Chang, J., Yu, J., Li, S., and Niu, H. 2018. Diversity of bacterial community during ensiling and subsequent exposure to air in whole-plant maize silage. Asian-Australasian Journal of Animal Sciences 31(9):1464-1473. https://doi.org/10.5713/ajas.17.0860.

Iqbal, M.A. 2014. Improving the growth and yield of Canola (Brassica napus L.) with seed treatment and foliar sprays of Brassica (Brassica naups L.) and moringa (Moringa olifera L.) leaf extracts. American-Eurasian Journal Agriculture and Environment Science 14(10):1067-1073. https://doi.org/10.5829/idosi.aejaes.2014.14.10.12429.

Islam, M.R., and Garcia, S.C. 2012. Effects of sowing date and nitrogen fertilizer on forage yield, nitrogen-and water-use efficiency and nutritive value of an annual triple-crop complementary forage rotation. Grass and Forage Science 67(1):96110. https://doi.org/10.1111/j.1365-2494.2011.00825.x.

Kaur, R., Garcia, S.C., and Fulkerson, W.J. 2009. Feeding time and sequence of forage rape and maize silage does not affect digestibility and rumen parameters in sheep. Animal Production Science 49(4):318-325. https://doi.org/10.1071/EA08261.

Kaur, R., Garcia, S.C., Fulkerson, W.J., and Barchia, I. 2010. Utilisation of forage rape (Brassica napus) and Persian clover (Trifolium resupinatum) diets by sheep: effects on whole tract digestibility and rumen parameters. Animal Production Science 50(1):59-67. https://doi.org/10.1071/ea08309.

Kung, J.L., Shaver, R.D., Grant, R.J., and Schmidt, R.J. 2018. Silage review: Interpretation of chemical, microbial, and organoleptic components of silages. Journal of Dairy Science 101:4020-4033. https://doi.org/10.3168/jds.2017-13909.

Lamb, A.R., and Evvard, J.M. 1916. Rape as material for silage. Journal of Agricultural Research 6(14):527-533.

Larsen, S.U., Hjort-Gregersen, K., Vazifehkhoran, A.H., and Triolo, J.M. 2017. Co-ensiling of straw with sugar beet leaves increases the methane yield from straw. Bioresource Technology 245:106-115.https://doi.org/10.1016/j.biortech.2017.08.117.

Li, M., Zhou, H., Zi, X., and Cai, Y. 2017. Silage fermentation and ruminal degradation of stylo prepared with lactic acid bacteria and cellulase. Animal Science Journal 88(10):1531-1537. https://doi.org/10.1111/asj.12795.

Lu, K., Wei, L., Li, X., Wang, Y., Wu, J., Liu, M., et al. 2019. Whole-genome resequencing reveals Brassica napus origin and genetic loci involved in its improvement. Nature Communications 10(1):1154. https://doi.org/10.1038/s41467-019-09134-9PMID:30858362.

McGarvey, J.A., Franco, R.B., Palumbo, J.D., Hnasko, R., Stanker, L., and Mitloehner, F.M. 2013. Bacterial population dynamics during the ensiling of Medicago sativa (alfalfa) and subsequent exposure to air. Journal of Applied Microbiology 114(6):1661-1670. https://doi.org/10.1111/jam.12179.

Muck, R.E. 2010. Silage microbiology and its control through additives. Revista Brasileira de Zootecnia 39:183-191. https://doi.org/10.1590/S1516-35982010001300021.

Nazli, M.H., Halim, R.A., Abdullah, A.M., Hussin, G., and Samsudin, A.A. 2019. Potential of four corn varieties at different harvest stages for silage production in Malaysia. Asian-Australasian Journal of Animal Sciences 32:224. https://doi.org/10.5713/ajas.18.0175 PMID:29879832. 
Ni, K.K., Zhao, J.Y., Zhu, B.G., Su, R.N., Pan, Y., Ma, J.K., et al. 2018. Assessing the fermentation quality and microbial community of the mixed silage of forage soybean with crop corn or sorghum. Bioresource Technology 265:563-567.

Parvin, S., Wang, C., Li, Y., and Nishino, N. 2010. Effects of inoculation with lactic acid bacteria on the bacterial communities of Italian ryegrass, whole crop maize, guinea grass and rhodes grass silages. Animal Feed Science and Technology 160:160166. https://doi.org/10.1016/j.anifeedsci.2010.07.010.

Santoso, B., Hariadi, B.T., Manik, H., and Abubakar H. 2011. Silage quality of king grass (Pennisetum purpureophoides) treated with epiphytic lactic acid bacteria and tannin of acacia. Media Peternakan 34(2):140140. https://doi.org/10.5398/medpet.2011.34.2.140.

Tian, J., Xu, N., Liu, B., Huan, H., Gu, H., Dong, C., et al. 2020. Interaction effect of silo density and additives on the fermentation quality, microbial counts, chemical composition and in vitro degradability of rice straw silage. Bioresource Technology 297:122412. https://doi.org/10.1016/j.biortech.2019.122412.

Wang, S., Li, J., Dong, Z., Chen, L., and Shao, T. 2018. Inclusion of alfalfa improves nutritive value and in vitro digestibility of various straw-grass mixed silages in Tibet. Grass and Forage Science 73(3):694-704. https://doi.org/10.1111/gfs.12365.

Wang, M., Wang, L., and Yu, Z. 2019. Fermentation dynamics and bacterial diversity of mixed lucerne and sweet corn stalk silage ensiled at six ratios. Grass and Forage Science 74:264-273. https://doi.org/10.1111/gfs.12431.

Xue, Y.L., Yin, G.M., Zhao, H.P., Bai, C.S., Sun, J.J., Yu, Z., et al. 2017. Nutritive value of desert wormwood (Artemisia desertorum Spreng.) silage in mixture with high-moisture maize straw. Grass and Forage Science 72(1):174-178. https://doi.org/10.1111/gfs.12202.

Yan, Y., Li, X., Guan, H., Huang, L., Ma, X., Peng, Y., et al. 2019. Microbial community and fermentation characteristic of Italian ryegrass silage prepared with corn stover and lactic acid bacteria. Bioresource Technology 279:166-173. https://doi.org/10.1016/j.biortech.2019.01.107.

Yang, J., Tan, H., and Cai, Y. 2016. Characteristics of lactic acid bacteria isolates and their effect on silage fermentation of fruit residues. Journal of Dairy Science 99(7):5325-5334. https://doi.org/10.3168/jds.2016-10952.

Yang, X., Kim, D.S., Choi, H.S., Kim, C.K., Thapa, L.P., Park, C., et al. 2017. Repeated batch production of 1,3-propanediol from biodiesel derived waste glycerol by Klebsiella pneumoniae. Chemical Engineering Journal 314:660-669. https://doi.org/10.1016/j.cej.2016.12.029.

Yu, J., Zhao, Y., Liu, B., Zhao, Y., Wu, J., and Yuan, X. 2016. Accelerated acidification by inoculation with a microbial consortium in a complex open environment. Bioresource Technology 216:294-301. https://doi.org/10.1016/j.biortech.2016.05.093.

Zhang, M., Wang, X., Cui, M., Wang, Y., Jiao, Z., and Tan, Z. 2018. Ensilage of oats and wheatgrass under natural alpine climatic conditions by indigenous lactic acid bacteria species isolated from high-cold areas. PLOS ONE 13(2): e0192368. https://doi.org/10.1371/journal.pone.0192368.

Zhao, J., Dong, Z., Li, J., Chen, L., Bai, Y., Jia, Y., Shao, T., et al. 2019. Effects of lactic acid bacteria and molasses on fermentation dynamics, structural and nonstructural carbohydrate composition and in vitro ruminal fermentation of rice straw silage. Asian-Australasian Journal of Animal Sciences 32(6):783. https://doi.org/10.5713/ajas.18.0543.

Zheng, M.L., Niu, D.Z., Jiang, D., Zuo, S.S., and Xu, C.C. 2017. Dynamics of microbial community during ensiling direct-cut alfalfa with and without LAB inoculant and sugar. Journal of Applied Microbiology 122:1456-1470. https://doi.org/10.1111/jam.13456. 